\title{
Eläinten hyvinvointia edistävät toimet hyvinvointimerkin takana - kirjallisuuskatsaus
}

\author{
Essi Wallenius ${ }^{1)}$, Tiina Kauppinen ${ }^{2)}$, Satu Raussi ${ }^{2)}$, Jarkko K. Niemi ${ }^{3)}$, Katriina Heinola ${ }^{3)}$ \\ 1)Armenta Benessi,essi.wallenius@armentabenessi.fi \\ ${ }^{2)}$ Eläinten hyvinvointikeskus, Luonnonvarakeskus, Latokartanonkaari 9, 00790 Helsinki, \\ tiina.kauppinen@luke.fi,satu.raussi@luke.fi \\ ${ }^{3)}$ Luonnonvarakeskus, Latokartanonkaari 9,00790 Helsinki, katriina.heinola@luke.fi, \\ jarkko.niemi@luke.fi
}

\section{TIIVISTELMÄ}

Eläinten hyvinvointia edistäviä toimia ja olosuhteita kartoitettiin eläinten hyvinvoinnista kertovaan pakkausmerkintään tähtäävässä hankkeessa. Merkintä edellyttäisi toimenpiteitä, jotka tutkitusti edistävät eläinten hyvinvointia. Hyvinvointi on eläinyksilön kokemus omasta psyykkisestä ja fyysisestä olotilastaan, ja parhaiten todennettavissa itse eläimestä. Eläimen kokemukseen vaikuttavat sen kyky sopeutua tarjottuihin olosuhteisiin, hoito, terveys, suhde ihmiseen ja muihin eläimiin, perimä sekä mahdollisuus toteuttaa fysiologian ja käyttäytymisen tarpeitaan. Jokaisen tuotantoeläimen hyvinvointia syntymästä teurastukseen ei voida yksilöllisesti todentaa kuluttajalle saakka. Eläimelle voidaan kuitenkin tarjota resursseja ja hoitoa, jotka todennetusti edistävät hyvinvointia, kuten reilusti tilaa, ulospääsy ja laidunnusmahdollisuus, lajinomaista käyttäytymistä ja tarpeita tukeva ravinto ja olosuhteet sekä terveydenhuolto. Tuotos ja kuolleisuus tilalla eivät yksin riitä hyvinvoinnin arviointiin. Korkea kuolleisuus tai alhainen tuotos voivat kertoa, että eläinten hyvinvointi on alentunut. Jalostuksesta johtuen eläin voi kuitenkin tuottaa jonkin aikaa hyvin myös oman hyvinvointinsa kustannuksella. Terveys on tärkeä hyvinvoinnin osatekijä, mutta sairaus ei aina ole hyvinvointiongelma. Esimerkiksi salmonella ja kampylobakteeri voivat aiheuttaa ihmisille vakaviakin tauteja, mutta eivät ole vastaava uhka kanojen hyvinvoinnille. Sen sijaan kivuliaat jalkojen ongelmat ovat huomattavia hyvinvointihaittoja. Paras mahdollinen kivunlievitys kivuliaissa toimenpiteissä on myös tärkeää hyvinvoinnille. Eläinten hyvinvointia edistää lajin ja eläimen elämänvaiheeseen sopiva ruokinta, jatkuva mahdollisuus puhtaaseen juomaveteen, sekä lajinmukaisen syömiskäyttäytymisen huomiointi. Naudat ja lampaat tarvitsevat karkearehua voidakseen hyvin. Sioille karkearehu tarjoaa tekemistä niin tonkimismateriaalina kuin syötävänä. Eläimen on välttämätöntä päästä toteuttamaan käyttäytymistarpeitaan kehittyäkseen normaalisti ja voidakseen fyysisesti ja psyykkisesti hyvin. Esimerkiksi emakolla on ennen porsimista tarve rakentaa porsimispesä, mikä onnistuu vapaaporsituskarsinassa, mutta ei porsitushäkissä. Kanojen orren käyttö, hiekkakylvyt ja siipien oikominen ovat käyttäytymismalleja, joiden toteuttaminen virikehäkissä on muita kanalatyyppejä hankalampaa. Laidunnus ja ulospääsy mahdollistavat useiden käyttäytymistarpeiden toteuttamisen. Laiduntaminen edistää nautojen hyvinvointia parantaen lihasten kuntoa ja sorkkaterveyttä sekä mahdollistaen sosiaalisen käyttäytymisen ja lajinomaisen syömis- ja lepokäyttäytymisen. Jo vuorokauden kytkemisen jälkeen naudalle tulee liikkumisen tarve. Ammattitaitoinen karjanhoitaja on lopulta yksi tärkeimmistä tekijöistä, että hyvinvointimerkintäjärjestelmään kuuluva tuotantoeläin oikeasti voi hyvin.

Asiasanat: eläimen hyvinvointi, pito-olot, hoitokäytännöt, terveys, käyttäytyminen, hyvinvointimerkintä

\section{Johdanto}

\section{Hyvinvointi on eläimen oma kokemus}

Eläimen hyvinvointi tarkoittaa eläimen omaa kokemusta sen fyysisestä ja psyykkisestä tilastaan (Broom 2007 (Martínez-Miró ym. 2016). Hyvinvointia voidaan arvioida mittaamalla muutoksia eläimen tilassa sekä havainnoimalla eläimen käyttäytymistä, terveyttä ja tuotosta. Esimerkiksi hedelmällisyysluvut tai karsinassa 
käytetyn kuivikkeen määrä voivat toimia mittareina hyvinvoinnin tasosta. Mittarit kertovat usein siitä, miten hyvin eläin pystyy sopeutumaan ympäristönsä asettamiin vaatimuksiin (Banett ym. 2001, Bobic ym. 2011).

Hyvinvoinnin edistämiseen on monia keinoja, joista osa toimii yksinkin, osa vaatii muita keinoja tuekseen. Joissain tapauksissa hyvinvoinnin parantaminen yhdellä osa-alueella voi heikentää sitä toisella osa-alueella. Parhaaseen lopputulokseen päästään yhdistämällä eri keinoja eläinlajien yksilölliset tarpeet huomioiden. Eläintuotannossa hyvinvoinnista huolehtiminen on tarpeen, koska tuotantoeläimet elävät stressaavassa ympäristössä. Stressiä aiheuttavat muun muassa tautipaine, suuri eläintiheys ja lajinmukaisen käyttäytymisen rajoittuminen (Bobic ym. 2011, Etim ym. 2013).

Eläimen hyvinvointi paranee ja stressi vähenee, kun eläimen pito-olosuhteita kohennetaan. Hyvinvointia heikentävät tekijät täytyy tunnistaa ja minimoida, mutta on tärkeää tunnistaa myös niitä tekijöitä, jotka lisäävät positiivisia kokemuksia eläimen elämään ja kohentavat siten hyvinvointia (Boissy ym. 2007, Herva, 2015). Hyvinvoinnilla on huomattava merkitys elintarviketeollisuuden ja kaupan imagolle (Vanhonacker ja Verbeke 2014), ja kuluttajakysyntä onkin johtanut eläinten hyvinvoinnista kertovien merkkien kehittämiseen maailmalla.

Tämä kirjoitus on eläinten hyvinvointimerkkihankkeen ensimmäinen osatyö, jonka tavoitteena oli kartoittaa tuotantoeläinten hyvinvointiin myönteisesti tai kielteisesti vaikuttavia tekijöitä ja niiden mittausmahdollisuuksia tieteellisen kirjallisuuden perusteella.

\section{Aineisto ja menetelmät}

Tutkimus toteutettiin kirjallisuustutkimuksena. Aluksi määriteltiin eläimet, joita selvityksessä tarkastellaan. $\mathrm{Ne}$ olivat siat, lihanaudat, lypsykarja, munivat kanat, broilerit, lampaat, porot ja vuohet. Tämän jälkeen kartoitettiin asiantuntijatyönä eläinten hyvinvointitekijät ja aihepiirit, joista tehtiin kirjallisuushaku. Selvityksessä päähuomio oli eläinten pito-olosuhteissa ja hoitokäytännöissä, jotka tutkimustiedon perusteella ovat olennaisia eläinten hyvinvointiin vaikuttavia tekijöitä. Kunkin tunnistetun hyvinvointitekijän osalta tarkasteltiin, mitä tutkimuskirjallisuus kertoo toimenpiteen vaikutuksista eläinten hyvinvointiin.

\section{Tulokset ja tulosten tarkastelu}

\section{Huonot olosuhteet stressaavat eläintä}

Eläimen pitopaikan olosuhteet, mukaan luettuna vallitseva sää, voivat aiheuttaa eläimelle stressiä. Ympäristöperäinen stressi voi näkyä eläimessä sairauksina vammoina tai aineenvaihduntaongelmina. Myös käsittely (Martínez-Miró ym. 2016) ja kuljetus stressaavat eläimiä, ja eläin voi altistua sosiaaliselle stressille (Camerlink ym. 2016) sen joutuessa uuteen ryhmään puolustamaan asemaansa tai resursseja (Pitts ym. 2000).

Stressillä tarkoitetaan tässä yhteydessä negatiivista stressiä (Carstens ja Moberg 2000), joka heikentää eläimen hyvinvointia. Stressi voi näkyä sairastuvuuden lisääntymisenä tai esimerkiksi käyttäytymisen muutoksina: sika voi stressaantuneena alkaa purra karsinatoverinsa häntää ja kana voi nokkia toista kanaa (Kops ym. 2013, Ursinus ym. 2014). Lehmillä stressi voi pienentää maitotuotosta ja altistaa sairauksille (Broom ja Johnson 1993, Bobic ym. 2011).

\section{Kuolleisuus on karkea hyvinvoinnin mittari}

Eläinten kuolleisuus tuotannon eri vaiheissa on karkea hyvinvoinnin mittari, ja kertoo eläinten hyvinvoinnista kokonaisen karjan tai parven tasolla. Korkea kuolleisuus tilalla viittaa siihen, että eläimet ovat elinaikanaan kärsineet sairauksista, tai muista hyvinvointia oleellisesti heikentävistä tekijöistä_(Weigel ym. 2003, Winckler ym. 2003, Mellor ja Stafford 2004).

Jos yksittäisen eläimen hyvinvoinnin tarkka seuraaminen ei ole mahdollista, voi seurantaa tehdä ryhmätasolla. Esimerkiksi broilereita kasvatetaan parvissa, joissa yksilöllinen havainnointi ei ole mahdollista. Tällöin koko parven kuolleisuuden seuraaminen on hyvä apuväline eläinten olosuhteiden 
tarkkailuun. Broilerit on ainoa tuotantoeläinryhmä, jolla kuolleisuuden raja-arvot on määritelty myös EUlainsäädännössä (EUR-Lex 2007). Hyvinvoinnin mittarina kuolleisuus toimii lähinnä tulevien kasvatuserien olosuhteiden potentiaalisen parantamisen puolesta. Niiden eläinten kohdalla, joiden kasvatusaikana kuolleisuuden kohonnut taso havaitaan, ovat hyvinvoinnin edistämistoimet toki jo myöhässä.

\section{Hyvinvoiva eläin ei aina ole tuottoisin eläin}

Melko yleinen harhakäsitys on, että tuottoisa eläin voi automaattisesti hyvin. Vaikka huonosti voiva eläin tuskin pääsee tuotoksen osalta huippulukemiin, ei korkea tuotostaso välttämättä takaa eläimen voivan hyvin. Esimerkiksi lehmän hyvinvoinnin ja maitotuotoksen välillä on yhteys (Hemsworth ym. 2002, Bobic' ym. 2011). Korkeat tuotosluvut kertovat usein siitä, että karjan jalostuksessa ja hoidossa on painotettu korkeaa tuotosta.

Suureen tuotokseen liittyy lypsylehmillä myös hedelmällisyys- ja utareterveysongelmia (Koivula ym. 2007, Oltenacu ja Broom 2010), eikä terveydeltään heikko lehmä kestä kauaa karjassa. Huono maitotuotos taas on yhteydessä korkeaan vasikkakuolleisuuteen (Torsein ym. 2014, Seppä-Lassila ym. 2016). Tuotosta oleellisempi mittari lieneekin elinikäistuotoksen ja kestävyyden yhdistelmä. Eläinten tuotoksessa näkyy yleensä tuottajan ammattitaito ja asenne. Motivoituneiden ja positiivisten tuottajien tiloilla maitotuotoskin on keskimääräistä suurempi (Hemsworth 2007, Hanna ym. 2009).

Sikatuotannossa on panostettu pahnueiden kokoon valitsemalla jalostukseen mahdollisimman suuria pahnueita tuottavia emakoita. Tälläkin on vaikutuksensa hyvinvointiin: suuri porsasmäärä ja isokokoiset porsaat saavat emakon laihtumaan etenkin jos ruokinnassa on puutteita, ja lisäävät lapahaavaumien riskiä (Lundgren 2012). Suurissa pahnueissa porsaita myös kuolee keskimääräistä enemmän ennen vieroitusikää (Roehe ja Kalm 2000, Pedersen ym. 2006, Su ym. 2007, Weber ym. 2007).

Myös nopeasti kasvaviksi jalostetut, suurella ruokahalulla varustetut broilerit voivat kärsiä hyvinvointiongelmista (Bessei ym. 2006). Nopeakasvuisilla roduilla kasvatuksenaikainen kuolleisuus on suurempaa kuin hitaammin kasvavilla (Bauer ym. 1996).

\section{Kipu kertoo hyvinvoinnin heikkenemisestä}

Kuten hyvinvointi, myös kipu on subjektiivinen kokemus, jonka voimakkuutta eläimillä ihmisen on usein vaikea arvioida (Hansen 1997, Sneddon ym. 2014). Jo pelkkä kivun tunnistaminen on haastavaa etenkin saaliseläimillä kuten naudoilla, lampailla ja hevosilla, sillä niiden kipusignaalit voivat olla hienovaraisia (Keating ym. 2012, Dalla Costa ym. 2014, Gleerup ym. 2015). Kipua voidaan arvioida lajille tyypillisen kipukäyttäytymisen, käyttäytymismuutosten ja eläimille annettavien valintatehtävien avulla, tai mittaamalla eläimen käyttäytymistä ennen ja jälkeen kipulääkkeen annostelun (Weary ym. 2006, Leslie ja Petersson-Wolfe 2012, Hokkanen ym. 2014, Gleerup ym. 2015).

\section{Kivuliaat toimenpiteet heikentävät hyvinvointia}

Kastraatio aiheuttaa eläimille kipua. Vaikka alle 7 vuorokauden ikäiset karjuporsaat saa EU-lainsäädännön mukaan kastroida ilman kivunlievitystä, porsaiden kipua hoidetaan ja lievitetään usein vapaaehtoisesti. Kastroinnilla on negatiivisia vaikutuksia myös lampaiden hyvinvointiin (Molony ym. 2002, Fitzpatrick 2006).

Nupoutus on yleinen käytäntö naudoilla etenkin maidontuotannossa. Vasikoiden nupouttaminen kuumalla kolvilla aiheuttaa vasikalle kipua, muuttaa vasikan käyttäytymistä ja aiheuttaa fysiologisen stressireaktion (Grøndahl-Nielsen ym. 1999, Stafford ja Mellor 2011). Nupoutuskipua voidaan hoitaa tehokkaasti paikallispuudutuksella, rauhoituksella ja pitkäkestoisella kipulääkkeellä (Grøndahl-Nielsen ym. 1999, Faulkner ja Weary 2000, Stafford ym. 2003, Stilwell ym. 2010, Stilwell ym. 2012, Allen ym. 2013). Sarvien poisto tai katkaisu ovat niin ikään eläimelle kivuliaita toimenpiteitä, joissa paikallispuudutus vähentää kipuoireita huomattavasti (Sylvester ym. 1998a, Sylvester ym. 1998b, Sutherland ym. 2002a, Sutherland ym. 2002b, Sylvester ym. 2004). 


\section{Oikea ruokinta on avainasemassa}

Tuotantoeläimille on lain mukaan ja tuotoksen varmistamiseksi tarjottava riittävästi niille soveltuvaa, laadukasta rehua. Esimerkiksi ummessa olevien lehmien, broileriemojen (Renema ja Robinson 2004) ja tiineiden emakoiden ruokintaa tyypillisesti rajoitetaan (Phillips 2016), jotta eläimet eivät söisi tuotantovaiheeseen nähden liikaa ja altistuisi liialliselle energiansaannille. Ruokinnan rajoittaminen aiheuttaa jatkuvaan syömiseen lajikehityksessä tottuneille märehtijöille tyypillisesti stressi- ja häiriökäyttäytymistä, ja tehokkaaseen kasvuun jalostetuilla eläimillä, kuten broileriemoilla ja sioilla, kroonista nälän tunnetta (Dixon ym. 2014), epänormaalia käyttäytymistä ja jopa liiallista juomista syötävän puutteessa (D’eath ym. 2008). Nälän tunnetta voidaan tehokkaasti tyydyttää tarjoamalla eläimille kuitupitoista karkearehua, jonka pureskeleminen vie aikaa ja tarjoaa vatsantäytteen lisäksi mielekästä tekemistä. Broileriemojen tapauksessa nykyjalosteilla ongelmaan ei ole suoraa ratkaisua (D'eath ym. 2008).

\section{Terveys on osa hyvinvointia}

Tuotantoeläinten terveyttä korostetaan eläintuotannossa paitsi eläinten hyvinvoinnin, myös elintarvikehygienian ja tuoteturvallisuuden vuoksi. Terveys, hyvinvointi ja hygienia eivät aina kulje käsi kädessä. Esimerkiksi salmonellan saneeraaminen kanaloissa on kuluttajien kannalta ensiarvoisen tärkeää, mutta kanojen hyvinvoinnin kannalta sillä ei ole vastaavaa merkitystä (Chai ym. 2016).

Sioilla salmonella voi toissijaisesti olla heikentyneen hyvinvoinnin merkki, sillä stressaantuneet siat erittävät stressihormonia, joka mahdollistaa salmonellan runsastumisen (Evangelopoulou ym. 2014, Martinez-Miro ym. 2016). Stressaantuneet siat ulostavat enemmän ja levittävät siten salmonellaa ympäristöönsä (Beloeil ym. 2004).

Nautakarjan tyypillisimpiä monisyisiä terveysongelmia ovat utaretulehdukset ja ontuminen (Haskell ym., 2006), jotka myös heikentävät maitotuotosta (Rajala-Shultz 1999, Armory ym. 2008).

\section{Lisätilan merkitys hyvinvoinnille ei aina ole yksiselitteinen}

Eläimillä on oltava tuotanto-oloissakin riittävästi tilaa, jotta ne voivat muun muassa toteuttaa luontaisia käyttäytymistarpeitaan ja päästä helposti resurssien kuten veden ja ruoan luo. Tilan määrää tärkeämpi tekijä on kuitenkin usein tilan laatu: suurikaan tila ei ilman virikkeitä ja toimivaa tilajakoa palvele eläinten hyvinvointia, kun taas pienempi tila tarvittavine ominaisuuksineen voi parantaa eläinryhmän sisäistä dynamiikkaa, tarjota tekemistä ja taata oman rauhan sitä tarvitseville eläimille. Esimerkiksi sioilla on todettu, että karsinatilan kasvattaminen edistää porsaiden hyvinvointia tiettyyn pisteeseen asti, mutta tuon pisteen jälkeen sillä ei ole merkitystä (Herman ym. 2017, Turner ym. 2000). Lisäksi sioilla tilan kasvattaminen menettää merkityksensä, jos tarjolla ei ole virikemateriaalia. Ryhmissä pidettävät tiineet emakot hyötyvät lisätilasta, kun niiden väliset yhteenotot vähenevät.

Kanat viihtyvät väljästi: matala eläintiheys pienentää höyhenten nokkimisen riskiä ja höyhenpeite pysyy paremmassa kunnossa (Hansen ja Braastad 1994, Bestman ym. 2009).

\section{Kytkeminen rajoittaa lajinmukaista käyttäytymistä}

Monessa EU-maassa lehmiä on pidetty parsinavetoissa yleisemmin kuin pihatoissa (Veissier ym. 2008), vaikka pihatot ovatkin viime aikoina yleistyneet. Kytkettynä parsinavetassa pitäminen rajoittaa naudan liikkumista ja vuorovaikutusta lajitovereiden kesken (Norring ym. 2012). Makuulle meno käy hitaammin ja jalkavaivoja esiintyy useammin parsinavettojen naudoilla (Krohn ja Munksgaard 1993).

Lehmien hyvinvointia voidaan edistää käyttämällä parsissa kumimattoja tai parsipetejä sekä runsasta kuivitusta. Säännöllinen jaloittelu ja mahdollisuuksien mukaan etenkin laidunnus vähentävät jonkin verran paikoillaan olon haitallisia vaikutuksia (Loberg ym. 2004, Vucemilo ym. 2012). Liikunnan tarve patoutuu parsilehmillä jo vuorokaudessa ja liikkumisenvapauden kannalta pihatto onkin lehmälle pääsääntöisesti parempi vaihtoehto (Regula ym. 2004, Popescu ym. 2013). 
Porsastuotannossa EU-alueella käytetään melko yleisesti porsitushäkkejä (EFSA 2007). Emakko viettää porsimisen yhteydessä 4-5 viikkoa kääntymisen estävässä häkissä. Tätä on pidetty kustannustehokkaana ja porsaskuolleisuuden kannalta vapaaporsimista parempana vaihtoehtona, mutta porsaskuolleisuuden osalta käsitykselle ei ole tutkimusnäyttöä. Vaikka vapaana porsiva emakko saattaa ruhjoa porsaitaan kuoliaaksi liikkuessaan karsinassa, porsaiden kokonaiskuolleisuus syntymästä vieroitukseen asti ei kuitenkaan ole sen suurempi kuin häkkiporsituksessakaan (Pedersen ym. 2011, Kilbride ym. 2012).

Porsitushäkkien lisäksi sikatuotannossa käytetään tiineytyshäkkejä emakon tiinehtymisen jälkeisinä viikkoina. Sekä tiineytys- että porsitushäkit rajoittavat emakkojen liikkumista ja altistavat ihon haavaumille (Bonde ym. 2004, Kilbride ym. 2009). Häkitys stressaa emakoita vapaana pitoon verrattuna (Jarvis ym. 2001, Oliviero ym. 2008). Häkissä sika ei voi toteuttaa lajinmukaista pesänrakennuskäyttäytymistään, millä on vaikutuksensa porsimiseen ja porsaiden elinvoimaisuuteen (Wischner ym. 2009).

Vapaina porsivat emakot porsivat nopeammin (Oliviero 2010), eikä niiden lisääntymismenestys kärsi, vaikka emakkoa ei pidettäisi tiineytyshäkissä tiineyden herkimpinä alkupäivinä. Siihen vaikuttavat enemmän eläinten hoito, ruokinta ja ryhmittely (Kongsted 2004, Spoolder ym. 2009, Quesnel ym. 2010).

\section{Kiinteä lattia ja kuiva, pehmeä makuualusta parhaita}

Lypsylehmät viettävät yli puolet ajastaan makuulla (Krohn ja Munksgaard 1993, Manninen ym. 2002, Hernandez-Mendo ym. 2007). Makuumukavuudella on huomattava vaikutus nautojen hyvinvointiin, kestävyyteen ja lehmien maitotuotokseen (Fisher ym. 2002, Cooper ym. 2007, Cooper ym. 2008, Calamari ym. 2009). Pehmeä makuualusta lisää naudan makuulla oloaikaa, vähentää ontumista ja edistää jalkaterveyttä (Rushen ym. 2007, Shuetz ja Cox 2014). Myös hiekka on hygieeninen ja toimiva parsimateriaali erityisesti jalkaterveyden kannalta (Espejo ym. 2006, Norring ym. 2008, Dufour ym. 2011). Lehmille mieluisinta on kuitenkin yleensä olki, jonka käytöllä on etuja etenkin poikimiskarsinassa (Proudfoot ym. 2013, Campler ym. 2015). Lihasonnien kuolleisuus on betonilattiaisessa karsinassa suurempi kuin olkikuivitetussa (Sundrum ja Rubelowski 2001). Ritilälattian päällä käytettävä kumipinnoite on parempi kuin pelkkä ritilälattia (Cozzi ym. 2013).

Pehkun materiaalilla on merkitystä myös siipikarjan hyvinvoinnille, etenkin jalkapohjien kunnolle. Pehkun kosteus altistaa broilerit jalkapohjasyöpymille (Mayne ym. 2007, de Jong ym. 2014). Pehkussa olki on huono materiaali. Parempia vaihtoehtoja ovat turve ja hiekka, jossa broilerit myös kylpevät mielellään. Myös munivat kanat hyötyvät pehkusta, etenkin jos sitä tarjotaan kanoille pienestä pitäen (Johnsen ym. 1998, Huber-Eicher and Sebö 2001, Bestman ym. 2009).

Rakolattioilla kasvatetut siat makaavat enemmän ja kärsivät jalkaongelmista enemmän, kuin kiinteällä lattialla kasvaneet siat (Guy ym. 2002, Candotti ym. 2003).

\section{Paras ryhmädynamiikka vakaissa, pysyvissä ryhmissä}

Monet lajit muodostavat ryhmissä vakaan hierarkian, joka edistää eläinyksilöiden hyvinvointia, kun turhat tappelut vältetään. Ryhmän dynamiikka muuttuu, kun siihen tuodaan uusia yksilöitä tai ryhmiä yhdistetään suuremmiksi ryhmiksi. Uudelleenryhmittelyyn liittyvä aggressiivisuus aiheuttaa eläimille stressiä ja tappeluista voi aiheutua vakaviakin vammoja. Uudelleenryhmittelyyn liittyvää aggressiivisuutta on havaittu ainakin sioilla, vuohilla, lampailla ja naudoilla (Meese ja Ewbank 1972, Zayan ja Dantzer 1990, Arey ja Edward 1998, Andersen ym. 1999, Pitts ym. 2000, Raussi ym. 2005, Jørgensen ym. 2006, Bøe ym. 2006, Fernandez ym. 2007, Andersen ym. 2008).

\section{Ulospääsy lisää lajinmukaisen käyttäytymisen mahdollisuuksia}

Laiduntaminen lisää märehtijöiden hyvinvointia. Se alentaa kuolleisuutta, vähentää poikimiseen liittyviä komplikaatioita ja edistää jalkaterveyttä. Naudoilla myös jaloittelutarhaan pääsy voi edistää lehmien hyvinvointia muun muassa jalkaterveyden ja sosiaalisen käyttäytymisen näkökulmasta (Bendixen ym. 1986, Keil ym. 2006, Thomsen ym. 2006, Rutherford ym. 2008, Rutherford ym. 2009, Corazzin ym. 2010, Burow ym. 2011). 
Sioilla ulkoilun hyvinvointivaikutukset eivät ole yhtä selkeitä. Laiduntaminen mahdollistaa sioille tärkeän, lajinmukaisen tutkimis- ja tonkimiskäyttäytymisen mutta voi lisätä muun muassa osteokondroosin riskiä ja siihen liittyviä jalkaongelmia (Yonezawa ym. 2012, Etterlin ym. 2014). Lisäksi sikojen ulkoiluun liittyy huoli tautiriskien, etenkin afrikkalaisen sikaruton ja salmonellan riskin kasvusta.

Munivien kanojen ulkoilu kannattaa järjestää pienehköissä ryhmissä, jolloin kanat käyttävät ulkoilualuetta enemmän kuin suurissa ryhmissä (Bubier ja Bradshaw 1998, Zeltner ym. 2004, Hegelund ym. 2005, Gilani ym. 2014). Ulkoilulla on todettu positiivisia vaikutuksia kanojen kognitiivisiin kykyihin. Kanoilla on ulkoilun yhteydessä kiinnitettävä huomiota myös valon määrään. Liian kirkas valo voi provosoida höyhenten nokkimiskäyttäytymistä ja kannibalismia. Päivänvalon ei kuitenkaan ole havaittu vaikuttavan kanojen höyhenpeitteen kuntoon (Drake ym. 2010). Myös kanojen ulkoilussa on hallittava tautiriskit.

\section{Hyvä ihmisen ja eläimen välinen suhde kannattaa}

Eläintenhoitajan asenne ja käyttäytyminen vaikuttavat eläinten hyvinvointiin ja terveyteen. Eläinten hyvä kohtelu ja käsittely vähentävät eläinten ihmistä kohtaan kokemaa pelkoa (Breuer ym. 2000, Boivin ym. 2003, Coleman ym. 2003, Hemsworth 2003, Waiblinger ym. 2006, Hemsworth 2007, Hanna ym. 2009, Hemsworth ja Coleman 2011).

\section{Lajinmukainen käyttäytyminen on hyvinvoinnin edellytys}

Kaikkia kotieläinlajeja yhdistää tarve lajinmukaiseen käyttäytymiseen, vaikka käyttäytymismallit ovat usein lajikohtaisia. Sikojen tarve tonkia ja tutkia ympäristöään on tutkimuksissa osoitettu käyttäytymistarve, jonka estyessä siat voivat suunnata tutkimiskäyttäytymisensä virheellisesti karsinatovereihinsa, mikä voi johtaa hännänpurentaan. Hännän- ja korvienpurentaa esiintyy sioilla keskimääräistä enemmän olosuhteissa, joissa sikoja pidetään ahtaasti, ilmanlaatu on heikko ja ruokinta on sopimatonta (Studnitz ym. 2007, Sonoda ym. 2013, Scollo ym. 2013, Scollo ym. 2016). Virikkeiden tarjoamisella voidaan ehkäistä sikojen epätoivottua käyttäytymistä.

Kanojen lajinmukaiseen käyttäytymiseen kuuluu olennaisesti orsien käyttö. Kanat viihtyvät orsilla etenkin yöaikaan. Koska suurin osa kanoista käyttää ortta yöllä, orren on oltava riittävän pitkä jotta kanat mahtuvat sille yhtä aikaa (Duncan ym. 1992, Olsson ja Keeling 2000, Olsson ja Keeling 2002, Schrader ja Müller 2009, Cook ym. 2011) Broilerien ei ole havaittu suosivan orsia yhtä paljon kuin kanojen, mutta ne käyttävät mielellään erilaisia tasoja ja ramppeja (Kaukonen ym. 2017).

\section{Johtopäätökset}

Tuotantoeläinten hyvinvointia voidaan edistää poistamalla hyvinvointiin negatiivisesti vaikuttavia asioita sekä lisäämällä eläimen elämään positiivisia kokemuksia ja mahdollisuuksia. Näitä ovat esimerkiksi laidunnusmahdollisuus, virikkeiden ja tonkimismateriaalien pito eläinten saatavilla, mukavan ja pehmeän makuupaikan järjestäminen eläimille, hyvästä hoitajan ja eläimen välisestä suhteesta huolehtiminen sekä lajitovereiden seuran tarjoaminen sopivan kokoisissa ja sopuisissa eläinryhmissä.

\section{Kiitokset}

Tämä tutkimus on osa Eläinten hyvinvointimerkintä suomalaisen eläintuotannon kilpailukyvyn ja laadun edistäjänä-hanketta. Tässä kirjoituksessa esitetyt näkemykset eläinten hyvinvointimerkinnästä ovat tutkijaryhmän näkemyksiä. Kiitos hankkeen rahoittajille (Maatilatalouden kehittämisrahasto, A-tuottajat, HKScan, Valio, Arla, Juustoportti food, Lidl, Maa- ja metsätaloustuottajain keskusliitto ja SEY Suomen Eläinsuojelu) sekä hanketyöpajoihin osallistuneille henkilöille. 


\section{Kirjallisuus}

Abriel, M., Jais, C. \& Heinz, B. 2014. Influence of pen design and space allowance on tail biting in weaning piglets. Landtechnik 696: 308-314.

Allen, K. A., Coetsee, J.F., EdwardsCallaway, L.N., Glynn, H., Dockweiler, J., KuKanich, B., Lin, H., Wang, C., Fraccaro, E., Jones, M. \& Bergamasco, L. 2013. The effect of timing of oral meloxicam administration on physiological responses in calves after cautery dehorning with local anesthesia. Journal of Dairy Science 96: 5194-5205. https://doi.org/10.3168/jds.2012-6251

Amory, J.R., Barker, Z.E., Wright, J.L., Mason, S.A., Blowey, R.W. \& Green, L.E. 2008. Associations between sole ulcer, white line disease and digital dermatitis and the milk yield of 1824 dairy cows on 30 dairy cow farms in England and Wales from February 2003-November 2004. Preventive Veterinary Medicine 83: 381-391.

https://doi.org/10.1016/j.prevetmed.2007.09.007

Andersen, I.L., Roussel, S., Ropstad, E., Braastad, B.O., Steinheim, G., Janczak, A.M., Jørgensen, G.M. \& Bøea, K.E. 2008. Social instability increases aggression in groups of dairy goats, but with minor consequences for the goats' growth, kid production and development. Applied Animal Behaviour Science 114: 132-148. https://doi.org/10.1016/j.applanim.2008.01.007

Arey D.S., \& Edwards, S.A. 1998. Factors influencing aggression between sows after mixing and the consequences for welfare and production. Livestock Production Science 56: 61-70. https://doi.org/10.1016/S0301-6226(98)00144-4 Beattie, V.E., O'Connell, N.E. \& Moss, B.W. 2000. Influence of environmental enrichment on the behaviour, performance and meat quality of domestic pigs. Livestock Production Science 65 : 71-79. https://doi.org/10.1016/S0301-6226(99)00179-7

Beloeil, P.-A., Chauvin, C. \& Proux, K. 2004. Impact of the Salmonella status of market-age pigs and the pre-slaughter process on Salmonella caecal contamination at slaughter. Veterinary Research 35: 513-530.

https://doi.org/10.1051/vetres:2004028

Bestman, M., Koene, P. \& Wagenaar, J.P. 2009. Influence of farm factors on the occurrence of feather pecking in organic reared hens and their predictability for feather pecking in the laying period Applied Animal Behaviour Science 121: 120-125. https://doi.org/10.1016/j.applanim.2009.09.007

Bobić, T., Mijić, P., Knežević, I., Šperanda, M., Antunović, B., Baban, M., Sakač, M., Frizon, E. \& Koturić, T. 2011. The impact of environmental factors on the milk ejection and stress of dairy cows. Biotechnology in Animal Husbandry 27: 919-927. https://doi.org/10.2298/BAH1103919B

Bøe, K.E., Berg, S. \& Andersen, I.L. 2006. Resting behaviour and displacements in ewes-effects of reduced lying space and pen shape. Applied Animal Behaviour Science 98: 249-259. https://doi.org/10.1016/j.applanim.2005.10.001

Boissy, A., Arnould, C., Chaillou, E., Désiré, L., Duvaux-Ponter, C., Greiveldinger, L., Leterrier, C., Richard, S., Roussel, S., Saint-Dizier, H., Meunier-Salaün, M.C. Valance, D. \& Veissier, I. 2007. Emotions and cognition: a new approach to animal welfare. Animal Welfare 16: Supplement 1

Boivin, X, Lwnsink, J., Tallet, C. \& Veissier, I. 2003. Stockmanship and farm animal welfare. Animal Welfare 12: 479492.

Bonde, M., Rousing, T. \& Badsberg, J.H. 2004. Associations between lying-down behaviour problems and body condition, limb disorders and skin lesions of lactating sows housed in farrowing crates in commercial sow herds. Livestock Production Science 87:179-187. https://doi.org/10.1016/j.livprodsci.2003.08.005

Breuer K, Hermsworth, P.H., Barnett, J.L., Matthews, L.R. \& Coleman, G.J. 2000. Behavioural response to humans and the productivity of commercial dairy cows. Applied Animal Behaviour Science 66: 273-288.

https://doi.org/10.1016/S0168-1591(99)00097-0

Broom, D.M. \& Johnson, K.G. 1993. Stress and animal welfare. London: Chapman \& Hall. 178p. https://doi.org/10.1007/978-94-024-0980-2

Bubier, N.E. \& Bradshaw R.H. 1998. Movement of flocks of laying hens in and out of the hen house in four free range systems. British Poultry Science 39: 5-6. https://doi.org/10.1080/00071669888025

Burow, E., Thomsen, P.T., Sørensen, J.T. \& Rousing, T. 2011. The effect of grazing on cow mortality in Danish dairy herds. Preventive Veterinary Medicine 100: 237-241. https://doi.org/10.1016/j.prevetmed.2011.04.001

Burow, E., Thomsen, P.T., Rousing, T. \& Sørensen, J.T. 2013. Daily grazing time as a risk factor for alterations at the hock integument in dairy cows. Animal 7: 160-166. https://doi.org/10.1017/S1751731112001395

Calamari, L., Calegari, F. \& Stefanini, L. 2009. Effect of different free stall surfaces on behavioural, productive and metabolic parameters in dairy cows. Applied Animal Behaviour Science 120: 9-17.

https://doi.org/10.1016/j.applanim.2009.05.013

Camerlink, I., Arnott, G., Farish, M. \& Turner, S.P. 2016. Complex contests and the influence of aggressiveness in pigs. Animal Behaviour 121: 71-78. https://doi.org/10.1016/j.anbehav.2016.08.021 
Campler, M.R., Munksgaard, L. \& Jensen, M.B. 2015. The effect of housing on calving behavior and calf vitality in Holstein and Jersey dairy cows. Journal of Dairy Science 98: 1797-1804. https://doi.org/10.3168/jds.2014-8726 Candotti, P., Rota Nodari, S., Archetti, I., Pezzotti, R., Caldara, G. \& Lazzarini, C. 2003. Influence of floor type on the incidence of leg weakness and on the frequency and severity of articular osteochondrotic lesions in Italian heavy pigs. In: Proceedings of XXIXth Annual Meeting of Italian Society for Swine Pathology and Breeding. Pp. 223-234. http://agris.fao.org/agris-search/search.do? recordID=IT2005601616

Chai, S., Cole, D., Nisler, A. \& Mahon, B.E. 2016. Poultry: the most common food in outbreaks with known pathogens, United States, 1998-2012. Epidemiology \& Infection 145: 316-325. https://doi.org/10.1017/S0950268816002375 Coleman, G.J., McGregor, M., Hemsworth, P.H., Boyce, J. \& Dowling, S. 2003. The relationship between beliefs, attitudes and observed behaviors of abattoir personnel in the pig industry. Applied Animal Behavior Science 82: 189200. https://doi.org/10.1016/S0168-1591(03)00057-1

Cook, N.J., Schaefer, A.L., Korver, D.R., Haley, D.B., Feddes, J.J.R. \& Church, J.S. 2011. Minimally-invasive assessments of the behavioral and physiological effects of enriched colony cages on laying hens. Open Agriculture Journal 5: 10-18. https://doi.org/10.2174/1874331501105010010

Cooper, M.D., Arney, R.D. \& Phillips, C.J.C. 2007. Two- or four-hour lying deprivation on the behavior or lactating dairy cows. Journal of Dairy Science 90: 1149-1158. https://doi.org/10.3168/jds.S0022-0302(07)71601-6

Cooper, M.D., Arney, R.D. \& Phillips, C.J.C. 2008. The effect of temporary deprivation of lying and feeding on the behaviour and production of lactating dairy cows. Animal 2: 275-283. https://doi.org/10.1017/S1751731107001164 Corazzin, M., Piasentier, E. \& Dovier, S. 2010. Effect of summer grazing on welfare of dairy cows reared in mountain tie-stall barns. Italian Journal of Animal Science 9: 304-312. https://doi.org/10.4081/ijas.2010.e59

Cozzi, G. Tessitore, E., Contiero, B. Rici, R., Gottardo, F. \& Brscic, M. 2013. Alternative solutions to the concrete fully-slatted floor for the housing of finishing beef cattle: effects on growth performance, health of the locomotor system and behaviour. Veterinary Journal 1972: 211-215. https://doi.org/10.1016/j.tvj1.2013.03.001

D'Eath, BD, Tolkamp, BJ. \& Kyriazakis, I. 2008. 'Freedom from hunger' and preventing obesity: the Animal welfare implications of reducing food quantity or quality. Animal Behaviour 77: 275-288.

https://doi.org/10.1016/j.anbehav.2008.10.028

de Jong, I. C., Gunnink, H. \& van Harn, J. 2014. Wet litter not only induces footpad dermatitis but also reduces overall welfare, technical performance, and carcass yield in broiler chickens. Journal of Applied Poultry Research 23: 51-58. https://doi.org/10.3382/japr.2013-00803

Dixon, L.M., Brocklehurst, S., Sandilands, V., Bateson, M., Tolkamp, B.J. \& D'Eath, R.B. 2014. Measuring motivation for appetitive behaviour: food-restricted broiler breeder chickens cross a water barrier to forage in an area of wood shavings without food. PLoS One 97: e102322. https://doi.org/10.1371/journal.pone.0102322

Drake K. A., Connelly, C.A. \& Dawkins, M.S. 2010. Influence of rearing and lay risk factors on propensity for feather damage in laying hens. British Poulty Science 51: 725-733. https://doi.org/10.1080/00071668.2010.528751

Duncan E.T., Appleby, C., Hughes, B.O. 1992. Effect of perches in laying cages on welfare and production of hens. British Poultry Science 33: 25-35. https://doi.org/10.1080/00071669208417441

Espejo, L.A., Endres, M.I. \& Salter, J.A. 2006. Prevalence of lameness in high-producing Holstein cows housed in freestall barns in Minnesota. Journal of Dairy Science 89: 3052-3058. https://doi.org/10.3168/jds.S00220302(06)72579-6

Etim, N., Offiong, E.E.A., Eyoh, G.D. \& Udo, M.D. 2013. Stress and animal welfare: an uneasy relationship. European Journal of Advanced Research in Biological and Life Sciences 1: 8-15.

Etterlin, P.E., Ytrehus, B., Lundeheim, N., Heldmer, E. Österberg, J. \& Ekman, S. 2014. Effects of free-range and confined housing on joint health in a herd of fattening pigs. BMC Veterinary Research 10: 208.

https://doi.org/10.1186/s12917-014-0208-5

Evangelopoulou, G., Filioussis, G., Kritas, S., Christodoulopoulos, G., Triantafillou, E.A. \& Burriel, A.R. 2015. Colonisation of pig gallbladders with Salmonella species important to public health. Veterinary Record 176: 174. https://doi.org/10.1136/vr.102822

Faulkner, P. M. \& Weary, D.M. 2000. Reducing pain after dehorning in dairy calves. Journal of Dairy Science 83: 2037-2041. https://doi.org/10.3168/jds.S0022-0302(00)75084-3

Fernandez, M.A., Alvarez, L. \& Larco, L. 2007. Regrouping in lactating goats increases aggression and decreases milk production. Small Ruminant Research 70: 228-232. https://doi.org/10.1016/j.smallrumres.2006.03.008

Fisher, A.D., Verkerk, G.A., Morrow, C.J. \& Matthwes, L.R. 2002.The effects of feed restriction and lying deprivation on pituitary-adrenal axis regulation in lactating cows. Livestock Production Science 73:255-263.

https://doi.org/10.1016/S0301-6226(01)00246-9

Fitzpatrick, J., Scott, M., Nolan, A. 2006. Assessment of pain and welfare in sheep. Small Ruminant Research 62: 5561. https://doi.org/10.1016/j.smallrumres.2005.07.028 
Gilani, A.M., Knowles, T.G. \& Nicol, C.J. 2014. Factors affecting ranging behaviour in young and adult laying hens British Poultry Science 55: 127-135. https://doi.org/10.1080/00071668.2014.889279

Grøndahl-Nielsen, C., Simonsen, H.B., Lund, J.D. \& Hesseholt, M. 1999. Behavioral, endocrine and cardiac responses in young calves undergoing dehorning with or without the use of sedation and analgesia. Veterinary Journal 158:14-20. https://doi.org/10.1053/tvj1.1998.0284

Guy, J.H., Rowlinson, P., Chadwick, J.P. \& Ellis, M. 2002. Behaviour of two genotypes of growing-finishing pig in three different housing systems. Applied Animal Behavoural Science 75: 193-206. https://doi.org/10.1016/S01681591(01)00197-6

Hanna, D., Sneddon, I. A. \& Beattie, V. E. 2009. The relationship between the stockperson's personality and attitudes and the productivity of dairy cows. Animal 3: 737-743. https://doi.org/10.1017/S1751731109003991

Hansen, I. \& Braastad, B.O. 1994. Effect of rearing density on pecking behaviour and plumage condition of laying hens in two types of aviary. Applied Animal Behaviour Science 40: 263-272. https://doi.org/10.1016/0168-1591(94)90067-1 Haskell, M.J., Rennie, L.J. \& Bowell, V.A. 2006. Housing system, milk production, and zero-grazing effects on lameness and leg injury in dairy cows. Journal of Dairy Science 89: 4259-4266. https://doi.org/10.3168/jds.S00220302(06)72472-9

Hemsworth, P.H. \& Coleman, G.J. 2011. Human-livestock interactions: The stockperson and the productivity and welfare of intensively farmed animals. 2nd ed. Wallingford, UK: CAB International.

Hemsworth, P.H. 2007. Ethical stockmanship. Australian Veterinary Journal 85: 194-200. https://doi.org/10.1111/j.1751-0813.2007.00112.x

Hemsworth, P.H. 2003. Human-animal interactions in livestock production. Applied Animal Behavour Science 81: 185-198. https://doi.org/10.1016/S0168-1591(02)00280-0

Hemsworth, P.H., Coleman, G.J., Barnett, J. L., Borg, S. \& Dowling, S. 2002. Stockpersons and the behavior and productivity of commercial dairy cows. Journal of Animal Science 80: 68-78.

Hemsworth, P.H., Coleman, G.J., Barnett, J. L., Borg, S. \& Dowling, S. 2002. Stockpersons and the behavior and productivity of commercial dairy cows. Journal of Animal Science 80: 68-78. https://doi.org/10.2527/2002.80168x Hernandez-Mendo, O., Keyserlingk, M.A.G., Veira, D.M. \& Weary, D.M. 2007. Effects of pasture on lameness in dairy cows. Journal of Dairy Science 90: 1209-1214. https://doi.org/10.3168/jds.S0022-0302(07)71608-9

Herman M. Vermeer, Nienke C. P. M. M. Dirx-Kuijken, and Marc B. M. Bracke. 2017. Exploration Feeding and Higher Space Allocation Improve Welfare of Growing-Finishing Pigs. Animals 75: 36.

https://doi.org/10.3390/ani7050036

Herva, T. 2015. Animal welfare and economics in beef production. Dissertationes Scholae Doctoralis Ad Sanitatem Investigandam Universitatis Helsinkiensis. Helsinki: University of Helsinki.

Huber-Eicher, B. \& Audigé, L. 1999. Analysis of risk factors for the occurrence of feather pecking in laying hen growers. British Poultry Science 40: 599-604. https://doi.org/10.1080/00071669986963

Jarvis, S., Van der Vegt, B.J., Lawrence, A.B., McLean, K.A., Deans, L.A., Chirnside, J. \& Calvert, S.K. 2001. The effect of parity and environmental restriction on behavioural and physiological responses of pre-parturient pigs. Applied Animal Behaviour Science 71: 203-216. https://doi.org/10.1016/S0168-1591(00)00183-0

Johnsen, P. F., Vestergaard, K.S. \& Nørgaard-Nielsen, G. 1998. Influence of early rearing conditions on the development of feather pecking and cannibalism in domestic fowl. Applied Animal Behaviour Science 60: 25-41. https://doi.org/10.1016/S0168-1591(98)00149-X

Jørgensen, G.H.M., Andersen, I.L. \& Bøe, K.E. 2006. Feed intake and social interactions in dairy goats-the effects of feeding space and type of roughage. Applied Animal Behaviour Science 107: 239-251.

https://doi.org/10.1016/j.applanim.2006.10.007

Kaukonen, E., Norring, M. \& Valros, A. 2017. Perches and elevated platforms in commercial broiler farms - use and effect on walking ability, incidence of tibial dyschondroplasia and bone mineral content. Animal 11: 864-871. https://doi.org/10.1017/S1751731116002160

Keil N.M., Wiederkehr, T.U., Friendlu, K. \& Wechsler, B. 2006. Effects of frequency and duration of outdoor exercise on the prevalence of hock lesions in tied Swiss dairy cows. Preventive Veterinary Medicine 74: 142-153.

https://doi.org/10.1016/j.prevetmed.2005.11.005

Kilbride, A.L., Mendl, M., Statham, P., Held, S., Harris, M., Cooper, S. \& Green, L.E. 2012. A cohort study of preweaning piglet mortality and farrowing accommodation on 112 commercial pig farms in England. Preventive Veterinary Medicine 104: 281-91. https://doi.org/10.1016/j.prevetmed.2011.11.011

Kilbride, A.L., Gillman, C.E. \& Green, L.E. 2009. A cross sectional study of the prevalence, risk factors and population attributable fractions for limb and body lesions in lactating sows on commercial farms in England. BMC Veterinary Research 5: 30.https://doi.org/10.1186/1746-6148-5-30 
Koivula, M., Mäntysaari, E.A., Negussie, E. \& Serenius, T. 2005. Genetic and phenotypic relationship among milk yield somatic cell count before and after clinical mastitis. Journal of Dairy Science 88: 827-833. https://doi.org/10.3168/jds.S0022-0302(05)72747-8

Kongsted, A.G. 2004. Reproduction performances and conditions of group-housed non-lactating sows. Copenhagen: The Royal Veterinary and Agricultural University. 119 p.

Kops, M.S., de Haas, E.N., Rodenburg, B., Ellen, E.D., Korte-Bouws, G.A.H., Olivier, B., Güntürküne, O., Bolhuis, J.E. \& Korte, S.M. 2013. Effects of feather pecking phenotype severe feather peckers, victims and non-peckers. on serotonergic and dopaminergic activity in four brain areas of laying hens Gallus gallus domesticus. Physiology \& Behavior 120: 77-82. https://doi.org/10.1016/j.physbeh.2013.07.007

Krohn, C.C. \& Munksgaard, L. 1993. Behaviour of dairy cows kept in extensive loose housing/pasture. or intensive tie stall. environments. II. Lying and lying-down behaviour. Applied Animal Behaviour Science 37: 1-16.

https://doi.org/10.1016/0168-1591(93)90066-X

Loberg, J, Telezhenko, E. \& Bergsten, C. 2004. Behavior and claw health in tied cows with varying access to exercise in an outdoor paddock. Applied Animal Behaviour Science 89:1-16. https://doi.org/10.1016/j.applanim.2004.04.009

Lundgren, H., Zumbach, B. \& Lundeheim, N. 2012. Heritability of shoulder ulcers and genetic correlations with mean piglet weight and sow body condition. Animal 61: 1-8. https://doi.org/10.1017/S1751731111001170

Manninen, E., de Passillé, A.M., Rushen, J., Norring, M. \& Saloniemi, H. 2002. Preferences of dairy cows kept in unheated buildings for different kind of cubicle flooring. Applied Animal Behaviour Science 75: 4.

https://doi.org/10.1016/S0168-1591(01)00206-4

Martínez-Miró, S., Tecles, F., Ramón, M., Escribano, D., Hernández, F., Madrid, J., Orengo, J., Martínez-Subiela, S., Manteca, X. \& Cerón, J.J. 2016. Causes, consequences and biomarkers of stress in swine: an update. BMC Veterinary Research 121: 171. https://doi.org/10.1186/s12917-016-0791-8

Mayne, R.K., Else, R.W. \& Hocking, Dr. P.M. 2007. High litter moisture alone is sufficient to cause footpad dermatitis in growing turkeys. British Poultry Science 48: 538-545. https://doi.org/10.1080/00071660701573045

Meese, G.B. \& Ewbank R. 1972. A note on instability of the dominance hierarchy and variations in level of aggression within groups of fattening pigs. Animal Production 14: 359-362. https://doi.org/10.1017/S0003356100011090

Mellor, D.J. \& Stafford, K.J. 2004. Animal welfare implications of neonatal mortality and morbidity in farm Animals. Veterinary Journal 168:118-33. https://doi.org/10.1016/j.tvj1.2003.08.004

Molony, V., Kent, J.E. \& McKendrick, I.J. 2002. Validation of a method for assessment of an acute pain in lambs. Applied Animal Behaviour Science 76: 215-238. https://doi.org/10.1016/S0168-1591(02)00014-X

Norring, M., Valros, A. \& Munksgaard, L. 2012. Milk yield affects time budget of dairy cows in tie-stalls. Journal of Dairy Science 95: 102-108. https://doi.org/10.3168/jds.2010-3458

Oliviero, C., Heinonen, M., Valros, A., Hälli, O. \& Peltoniemi, O.A. 2008. Effect of the environment on the physiology of the sow during late pregnancy, farrowing and early lactation. Animal Reproduction Science 105: 365-377. https://doi.org/10.1016/j.anireprosci.2007.03.015

Oliviero, C., Heinonen, M., Valros, A. \& Peltoniemi, O. 2010. Environmental and sow-related factors affecting the duration of farrowing. Animal Reproduction Science 119: 85-91. https://doi.org/10.1016/j.anireprosci.2009.12.009 Olsson, I.A. \& Keeling, L. J. 2000. Night-time roosting in laying hens and the effect of thwarting access to perches. Applied Animal Behavior Science 68: 243-256. https://doi.org/10.1016/S0168-1591(00)00097-6

Olsson, I.A. \& Keeling, L.J. 2002. The push-door for measuring motivation in hens: hens are motivated to perch at night. Animal Welfare 11: 11-19.

Oltenacu, P.A. \& Broom, D.M. 2010. The impact of genetic selection for increased milk yield on the welfare of dairy cows. Animal Welfare 19, Supplement 1:39-49.

Pedersen, L.J., Berg, P. \& Jorgensen, G. 2011. Neonatal piglet traits of importance for survival in crates and indoor pens. Journal Animal Science 894: 1207-1218. https://doi.org/10.2527/jas.2010-3248

Phillips, C.J.C. 2016. Nutrition and the welfare of farm animals. Dordrecht: Springer.

Pitts, A.D., Weary, D.M., Pajor, E.A. \& Fraser, D. 2000. Mixing at young ages reduces fighting in unacquainted domestic pigs. Applied Animal Behaviour Science 68: 191-197. https://doi.org/10.1016/S0168-1591(00)00104-0

Popescu, S., Borda, C. \& Sandru, C. 2013. Dairy cows welfare quality in tie-stall housing system with or without access to exercise. Acta Veterinaria Scandinavica 55: 43. https://doi.org/10.1186/1751-0147-55-43

Proudfoot, K.L., Jensen, M.B., Heegaard, P.M.H. \& Keyserlingk, M.A.G. 2013. Effect of moving dairy cows at different stages of labor on behavior during parturition. Journal of Dairy Science 96: 1638-1646.

https://doi.org/10.3168/jds.2012-6000

Quesnel, H., Boulot, S. \& Serriere, S. 2010. Post-insemination level of feeding does not influence embryonic survival and growth in highly prolific gilts. Animal Reproduction Science 120: 120-124.

https://doi.org/10.1016/j.anireprosci.2010.04.006 
Rajala-Schultz, P.J., Gröhn, Y.T. \& McCulloch, C.E. 1999. Effects of Milk Fever, Ketosis, and Lameness on Milk Yield in Dairy Cows. Journal of Dairy Science 82: 288-294. https://doi.org/10.3168/jds.S0022-0302(99)75235-5 Raussi, S., Niskanen, S., Siivonen, J., Hänninen, L., Hepola, H., Jauhiainen, L. \& Veissier, I. 2010. The formation of preferential relationships at early age in cattle. Behavioural Processes 84: 726-731. https://doi.org/10.1016/j.beproc.2010.05.005

Regula, G., Danuser, J. \& Spycher, B. 2004. Health and welfare of dairy cows in different husbandry systems in Switzerland. Preventive Veterinary Medicine 15: 247-264. https://doi.org/10.1016/j.prevetmed.2004.09.004

Renema, R.A. \& Robinson, F.E. 2004. Defining normal: comparison of feed restriction and full feeding of female broiler breeders. World's poultry Science Journal 60: 508-522. https://doi.org/10.1079/WPS200434

Rushen, J., Haley, D. \& de Passillé, A.M. 2007. Effect of softer flooring in tie stalls on resting behavior and leg injuries of lactating cows. Journal of Dairy Science 90: 3647-3651. https://doi.org/10.3168/jds.2006-463

Schrader, L. \& Müller, B. 2009. Night-time roosting in the domestic fowl: The height matters. Applied Animal Behaviour Science 121:179-183. https://doi.org/10.1016/j.applanim.2009.09.010

Schuetz, E. \& Cox, N.R. 2014. Effects of short-term repeated exposure to different flooring surfaces on the behavior and physiology of dairy cattle. Journal of Dairy Science 97: 2753-2762. https://doi.org/10.3168/jds.2013-7310

Scollo, A. \& Gottardo, B.C.F. 2016. Frequency of tail lesions and risk factors for tail biting in heavy pig production from weaning to $170 \mathrm{~kg}$ live weight. Veterinary Journal 207: 92-98. https://doi.org/10.1016/j.tvj1.2015.10.056

Seppä-Lassila, L., Eerola, U., Orro, T., Härtel, H., Simojoki, H., Autio, T., Pelkonen, S. \& Soveri, T. 2017. Health and growth of Finnish beef calves and the relation to acute phase response. Livestock science 196: 7-13.

https://doi.org/10.1016/j.livsci.2016.12.007

Spoolder, H.A.M., Geudeke, M.J., Van der Peet.Schwering, C.M.C. \& Soede, N.M. 2009. Group housing of sows in early pregnancy: A review of success and risk factors. Livestock Science 125: 1-14.

https://doi.org/10.1016/j.livsci.2009.03.009

Stafford, K.J., \& Mellor, D.J. 2011. Addressing the pain associated with disbudding and dehorning in cattle. Applied Animal Behaviour Science 135: 226-231. https://doi.org/10.1016/j.applanim.2011.10.018

Stafford, K.J., Mellor, D.J., Todd, S.E., Ward, R.N. \& McMeekan, C.M. 2003. The effect of different combinations of lignocaine, ketoprofen, xylazine and tolazoline on the acute cortisol response to dehorning in calves. New Zealand Veterinary Journal 51: 219-226. https://doi.org/10.1080/00480169.2003.36370

Stilwell, G., Lima, M.S., Carcalho, R.C. \& Broom, D.M. 2012. Effects of hot-iron disbudding, using regional anaesthesia with and without carprofen, on cortisol and behaviour of calves. Research in Veterinary Science 92: 338341. https://doi.org/10.1016/j.rvsc.2011.02.005

Studnitz, M., Jensen, M.B. \& Pedersen, L.J. 2007. Why do pigs root and what will they root? A review on the exploratory behavior of pigs in relation to environmental enrichment. Applied Animal Behaviour Science 107: 183197. https://doi.org/10.1016/j.applanim.2006.11.013

Sylvester, S.P., Stafford, K.J., Mellor, D.J., Bruce, R.A. \& Ward, R.N. 2004. Behavioural responses of calves to amputation dehorning with and without local anaesthesia. Australian Veterinary Journal 82: 697-700.

https://doi.org/10.1111/j.1751-0813.2004.tb12162.x

Sylvester, S.P., Stafford, K.J., Mellor, D.J., Bruce, R.A. \& Ward, R.N. 1998a. Acute cortisol responses of calves to scoop dehorning using local anaesthesia and/or cautery of the wound. Australian Veterinary Journal 76: 118-122. https://doi.org/10.1111/j.1751-0813.1998.tb14542.x

Sylvester, S.P., Stafford, K.J., Mellor, D.J., Bruce, R.A. \& Ward, R.N. 1998b. Acute cortisol responses of calves to four methods of dehorning by amputation. Australian Veterinary Journal 76: 123-126. https://doi.org/10.1111/j.17510813.1998.tb14544.x

Torsein, M., Jansson-Mörk , M., Lindberg, A., Hallén-Sandgren, C. \& Berg, C. 2014. Associations between calf mortality during days 1 to 90 and herd-level cow and production variables in large Swedish dairy herds. Journal of Dairy Science 97: 6613-6621. https://doi.org/10.3168/jds.2014-7949

Ursinus, W.W., Wijnen, H.J., Bartels, A.C., Dijvesteijn, N., van Reenen, C.G. \& Bolhuis, J.E. 2014. Damaging biting behaviors in intensively kept rearing gilts: the effect of jute sacks and relations with production characteristics. Journal of Animal Sciience 92: 5193-5202. https://doi.org/10.2527/jas.2014-7918

Turner, S.P., Ewen, M. \& Rooke, J.A. 2000. The effect of space allowance on performance, aggression and immune competence of growing pigs housed on straw deep-litter at different group sizes. Livestock Production Science 66: 4755. https://doi.org/10.1016/S0301-6226(00)00159-7

Vanhonacker, F. \& Verbeke, W. 2014. Public and Consumer Policies for Higher Welfare Food Products: Challenges and Opportunities. Journal of Agricultural and Environmental Ethics 27: 153-171. https://doi.org/10.1007/s10806-0139479-2

Veissier, I., Andanson, S. \& Dubroeucq, H. 2008. The motivation of cows to walk as thwarted by tethering. Journal of Animal Science 86: 2723-2729. https://doi.org/10.2527/jas.2008-1020 
Vermeer, H.M., Dirx-Kuijken, N.C.P.M.M. \& Bracke, M.B.M. 2017. Exploration feeding and higher space allocation improve welfare of growing-finishing pigs. Animals 7: 36. https://doi.org/10.3390/ani7050036

Vucemilo, M., Matkovic, K. Stokovic, I., Kovacevic, S. \& Benic, M. 2012. Welfare assessment of dairy cows housed in a tie-stall system. Mljekarstvo 62: 62-67.

Waiblinger, S., Boivin, X., Pedersen, V., Tosi, M.V., Janczak, A.M., Visser, E.K. \& Jones, R.B. 2006. Assessing the human-animal relationship in farmed species: A critical review. Applied Animal Behaviour Science 101: $185-242$. https://doi.org/10.1016/j.applanim.2006.02.001

Weber, R., Keil, N.M., Fehr, M. \& Horat, R. 2009. Factors affecting piglet mortality in loose farrowing systems on commercial farms. Livestock Science 124: 216-222. https://doi.org/10.1016/j.livsci.2009.02.002

Weigel, K.A., Palmer, R.W. \& Caraviello, D.Z. 2003. Investigation of factors affecting voluntary and involuntary culling in expanding dairy herds in Wisconsin using survival analysis. Journal of Dairy Science 86:1482-1486. https://doi.org/10.3168/jds.S0022-0302(03)73733-3

Winckler, C., Capdeville, J., Gebresenbet, G., Hörning, B., Roiha, U., Tosi, M. \& Waiblinger, S. 2003. Selection of parameters for on-farm welfare-assessment protocols in cattle and buffalo. Animal Welfare 12: 619-624.

Wischner, D., Kemper, N. \& Krieter, J. 2009. Nest-building behaviour in sows and consequences for pig husbandry. Livestock Science 124: 1-8. https://doi.org/10.1016/j.livsci.2009.01.015

Yonezawa, T., Takahashi, A., Imai, S., Okitsu, A., Komiyama, S., Irimajiri, M., Matsuura, A., Yamaxaki, A. \& Hodate, K. 2012. Effects of outdoor housing of piglets on behavior, stress reaction and meat characteristics. Asian-Australasian Journal of Animal Science 256: 886-894. https://doi.org/10.5713/ajas.2011.11380

Zayan R. \& Dantzer R. 1990. Social stress in farm animals. The Hague, The Netherlands: Martinus Nijhoff.

EUR-Lex 2007: Council Directive 2007/43/EC of 28 June 2007 laying down minimum rules for the protection of chickens kept for meat production (Text with EEA relevance): https://eur-lex.europa.eu/legal-

content/EN/TXT/?uri=celex\%3A32007L0043 